\title{
Distribution and dissemination of the Val1016lle and Phe1534Cys Kdr mutations in Aedes aegypti Brazilian natural populations
}

Jutta Gerlinde Birggitt Linss ${ }^{1,2+}$, Luiz Paulo Brito ${ }^{1,2+}$, Gabriela Azambuja Garcia ${ }^{1,2}$, Alejandra Saori Araki ${ }^{3}$, Rafaela Vieira Bruno ${ }^{3,4}$, José Bento Pereira Lima ${ }^{1,2}$, Denise Valle ${ }^{4,5^{*}}$ and Ademir Jesus Martins ${ }^{1,2,4^{*}}$

\begin{abstract}
Background: The chemical control of the mosquito Aedes aegypti, the major vector of dengue, is being seriously threatened due to the development of pyrethroid resistance. Substitutions in the 1016 and 1534 sites of the voltage gated sodium channel ( $\mathrm{AaNav}$ ), commonly known as kdr mutations, confer the mosquito with knockdown resistance. Our aim was to evaluate the allelic composition of natural populations of Brazilian Ae. aegypti at both $k d r$ sites.

Methods: The AaNav IIIS6 region was cloned and sequenced from three Brazilian populations. Additionally, individual mosquitoes from 30 populations throughout the country were genotyped for 1016 and 1534 sites, based in allele-specific PCR. For individual genotypes both sites were considered as a single locus.

Results: The 350 bp sequence spanning the IIIS6 region of the AaNav gene revealed the occurrence of the $k d r$ mutation Phe1534Cys in Brazil. Concerning the individual genotyping, beyond the susceptible wild-type ( $\mathrm{Nav}_{v}^{\mathrm{S}}$ ), two kdr alleles were identified: substitutions restricted to the 1534 position $\left(\mathrm{Nav}^{\mathrm{R} 1}\right)$ or simultaneous substitutions in both 1016 and 1534 sites $\left(\mathrm{Na}_{v}{ }^{\mathrm{R}}{ }^{2}\right.$ ). A clear regional distribution pattern of these alleles was observed. The $\mathrm{Na}_{v}{ }^{\mathrm{R} 1} k d r$ allele occurred in all localities, while $\mathrm{Nav}^{\mathrm{R} 2}$ was more frequent in the Central and Southeastern localities. Locations that were sampled multiple times in the course of a decade revealed an increase in frequency of the $k d r$ mutations, mainly the double mutant allele $\mathrm{Nav}_{v}{ }^{\mathrm{R} 2}$. Recent samples also indicate that $\mathrm{Nav}_{v}{ }^{\mathrm{R} 2}$ is spreading towards the Northern region.

Conclusions: We have found that in addition to the previously reported Val1016lle kdr mutation, the Phe1534Cys mutation also occurs in Brazil. Allelic composition at both sites was important to elucidate the actual distribution of $k d r$ mutations throughout the country. Studies to determine gene flow and the fitness costs of these $k d r$ alleles are underway and will be important to better understand the dynamics of Ae. aegypti pyrethroid resistance.
\end{abstract}

Keywords: $k d r$ mutation, Pyrethroid resistance, Vector control, Aedes aegypti, Dengue in Brazil, Sodium channel

\section{Background}

Dengue is currently the most important arbovirus in the world. Dengue has spread widely in urban areas of tropical and subtropical regions during the last decades, including countries of Southeast Asia, Pacific and Latin America [1]. Between 2001-2011, almost 10 million dengue cases were reported in Latin America, almost $60 \%$ of these

\footnotetext{
* Correspondence: dvalle@ioc.fiocruz.br; ademirjr@ioc.fiocruz.br ${ }^{\dagger}$ Equal contributors

${ }^{4}$ Instituto Nacional de Ciência e Tecnologia em Entomologia Molecular, Rio de Janeiro, RJ, Brazil

'Laboratório de Fisiologia e Controle de Artrópodes Vetores, Instituto Oswaldo Cruz - FIOCRUZ, Rio de Janeiro, RJ, Brazil

Full list of author information is available at the end of the article
}

were registered in Brazil [2]. Dengue mortality can reach up to $5 \%$ of the confirmed infection cases. In addition, in tropical dengue endemic countries a loss of 1,300 disabilityadjust life years (DALYs) per million people is estimated [1]. Aedes aegypti is the main dengue vector throughout the world. Control of this mosquito consists primarily of the elimination of artificial and disposable water flooded larvae breeding sites and application of insecticides. The WHO Pesticide Evaluate Scheme (WHOPES) recommends ten different compounds to eliminate larvae, including neurotoxicants (organophosphates, pyrethroids and neocotinoids), Insect Growth Regulators (chitin synthesis inhibitors and juvenile hormone analogs), and Bacillus

\section{Biomed Central}


(like B. thuringiensis var israelensis) as larvicides. However, fewer formulations are recommended for the control of adult mosquitoes, mostly five pyrethroids and one organophosphate [3].

Given their rapid mode of action and low hazardous effect to the environment, compared to organophosphate insecticides, the use of pyrethroids has increased significantly in the last two decades. Nowadays, pyrethroids are widely employed in and around households, even for pet protection and mosquito control [4]. Since Ae. aegypti is essentially an urban mosquito, it is constantly exposed to strong pyrethroid selection. As a consequence, many Ae. aegypti populations worldwide are becoming resistant to this class of insecticides [5].

Pyrethroids target the transmembrane voltage gated sodium channel $\left(\mathrm{Na}_{V}\right)$ from the insect nervous system, triggering rapid convulsions followed by death, a phenomenon known as knockdown effect [6]. The $\mathrm{Na}_{\mathrm{V}}$ is composed of four homologous domains (I-IV), each with six hydrophobic segments (S1-S6) [7]. Because the $\mathrm{Na}_{V}$ is a very conserved protein among invertebrates, small changes are permissive without impairing its physiological role [8]. A series of mutations have been identified in different orders of insects and acarids that affect pyrethroid susceptibility, thus being referred to as 'knockdown resistance' or $k d r$ mutations [9]. These $k d r$ mutations may lead to conformational changes in the whole channel that maintain its physiological role but avoid insecticide action [10].

In insects, the most common $k d r$ mutation is the substitution Leu/Phe in the 1014 site (numbered according to the Musca domestica $\mathrm{Na}_{V}$ primary sequence), followed by the Leu/Ser substitution in the same position, in Anopheles and Culex mosquitoes [11]. In the Ae. aegypti $\mathrm{Na}_{\mathrm{V}}\left(A a N a_{V}\right)$, the 1014 Leu codon is encoded by CTA, rather than TTA as in Anopheles and Culex mosquitoes. This means that two substitutions would have to be simultaneously selected in the same codon in order to change Leu to Phe (TTT) or Ser (TCA) [12]. Although several mutations have been identified in natural populations at $A a N a_{V}$ [13], only the Val1016Ile and Phe1534Cys substitutions were clearly related to the loss of pyrethroid susceptibility $[12,14]$. These sites are placed respectively in the IIS6 and IIIS6 regions of the channels that are known to be involved in the interaction with pyrethroids [10]. It has been previously observed that in Latin America the 1016 Ile $k d r$ is highly disseminated $[12,15,16]$ and its frequency is rapidly increasing in localities with intense pyrethroid use, such as Brazil and Mexico [15,16]. High frequencies of 1534 Cys $k d r$ were also observed in Grand Cayman and Martinique [14,17].

In the current study, we demonstrate that the1534 Cys $k d r$ mutation is present in Brazil together with the 1016
Ile allele previously found. The simultaneous occurrence of both $k d r$ mutations at the 1016 and 1534 was found in several localities. Spatial and temporal analysis of these alleles point to a significant role of the $k d r$ mutations in pyrethroid resistance in Brazil.

\section{Methods \\ Mosquito samples}

Ae. aegypti used for $k d r$ genotyping originated from the same samples evaluated by the Brazilian Aedes agypti Insecticide Resistance Monitoring Network, collected with ovitraps according to recommendations of the Brazilian Dengue Control Program [18]. Adult mosquitoes resulting from the eggs collected in the field (F0 generation) were preferentially used. However, in some cases only the following generations reared in the laboratory were available. Details regarding sampling as well as individual data from mosquitoes used for $k d r$ genotyping are found in Table 1. A total of 30 localities were analyzed at least once, with AJU, SGO, MSR and VIT analyzed for two-four time-points.

\section{Genotyping assays}

Thirty individual mosquitoes from each locality were genotyped at both 1016 and 1534 positions from genomic DNA by allele-specific PCR (AS-PCR) which contains a common primer and two specific primers targeting each polymorphic site. The specificity is attained in the 3 '-end, strengthened by a transition three nucleotides before [19]. Additionally, a GC-tail of different sizes was added at the 5 '-end of these primers so products can be distinguished by their melting temperature (Tm) in a melting curve analysis or by electrophoresis [12,20,21]. Primer sequences are shown in Table 2. DNA extraction and amplification of the 1016 (Val/Ile) site were conducted as previously described [15]. The reaction for the 1534 (Phe/Cys) site was optimized from previous work $[16,22]$. In both cases, PCR was carried out with the GoTaq Green Master Mix kit (Promega), $0.5 \mu \mathrm{L}$ of genomic DNA, $0.24 \mu \mathrm{M}$ of the common primer, 0.12 and $0.24 \mu \mathrm{M}$ of the specific primers (1534 Cys ${ }^{k d r}$ and 1534 Phe), in a total volume of $12.5 \mu \mathrm{L}$. Denaturing, annealing and extension conditions were, respectively, $95^{\circ} \mathrm{C} / 30^{\prime \prime}, 54^{\circ} \mathrm{C} / 40^{\prime \prime}$ and $72^{\circ} \mathrm{C} / 45^{\prime \prime}$, in 32 cycles. Alternatively, real-time PCR was conducted with the SYBR Green PCR Master Mix kit (LifeTechnologies/Applied Biosystems), $1 \mu \mathrm{L}$ genomic DNA and $0.24 \mu \mathrm{M}$ of each primer, in a total volume of $10 \mu \mathrm{L}$. The best conditions for denaturing, annealing and extension were respectively $95^{\circ} \mathrm{C} / 15^{\prime \prime}, 54^{\circ} \mathrm{C} / 15^{\prime \prime}$ and $60^{\circ} \mathrm{C} / 30^{\prime \prime}$, in 33 cycles, followed by a standard melting curve stage. The amplification reaction and melting curve analyses were performed in a StepOne Plus or in a 7500 Real-time PCR system (LifeTechnologies/Applied Biosystems). DNA pools of individuals from CGR, STR 
Table 1 Aedes aegypti populations used in this study

\begin{tabular}{|c|c|c|c|c|c|c|c|}
\hline Code & Municipality & Locality state & Coordinates & Brazilian macroregion & $\begin{array}{c}\text { Year of } \\
\text { sampling }\end{array}$ & $\begin{array}{l}\text { Generation used } \\
\text { in the assays }\end{array}$ & Gender \\
\hline \multirow[t]{4}{*}{ AJU } & Aracajú & Sergipe & $10^{\circ} 54^{\prime} \mathrm{AJU}$ S, $37^{\circ} 04^{\prime} \mathrm{O}$ & Northeast & 2002 & F1 & Males \\
\hline & & & & & 2006 & $\mathrm{~F} 1$ & Females \\
\hline & & & & & 2010 & $\mathrm{~F} 1$ & Females \\
\hline & & & & & 2012 & F0 & Males \\
\hline APG & Aparecida de Goiânia & Goiás & $16^{\circ} 48^{\prime} \mathrm{S}, 49^{\circ} 14^{\prime} \mathrm{O}$ & Central-west & 2012 & F0 & Males \\
\hline BEL & Belém & Pará & $1^{\circ} 27^{\prime} \mathrm{S}, 48^{\circ} 30^{\prime} \mathrm{O}$ & North & 2010 & $\mathrm{~F} 1$ & Males \\
\hline BVT & Boa Vista & Roraima & $2^{\circ} 49^{\prime} \mathrm{N}, 60^{\circ} 40^{\prime} \mathrm{O}$ & North & 2011 & $\mathrm{~F} 1$ & Males \\
\hline CAC & Caicó & Rio Grande do Norte & $6^{\circ} 27^{\prime} S, 37^{\circ} 05^{\prime} \mathrm{O}$ & Northeast & 2010 & F1 & Females \\
\hline CAS & Castanhal & Pará & $1^{\circ} 17^{\prime} \mathrm{S}, 47^{\circ} 55^{\prime} \mathrm{O}$ & North & 2011 & F0 & Males \\
\hline CBL & Campos Belos & Goiás & $13^{\circ} 02^{\prime} \mathrm{S}, 46^{\circ} 45^{\prime} \mathrm{O}$ & Central-west & 2011 & F0 & Males \\
\hline CGR & Campo Grande & Mato Grosso do Sul & $20^{\circ} 26^{\prime} \mathrm{S}, 54^{\circ} 38^{\prime} \mathrm{O}$ & Central-west & 2010 & F0 & Males \\
\hline CIT & Cachoeiro do Itapemirim & Espírito Santo & $20^{\circ} 51^{\prime} \mathrm{S}, 41^{\circ} 06^{\prime} \mathrm{O}$ & Southeast & 2012 & F0 & Males \\
\hline CLT & Colatina & Espírito Santo & $19^{\circ} 32^{\prime} \mathrm{S}, 40^{\circ} 37^{\prime} \mathrm{O}$ & Southeast & 2011 & F0 & Males \\
\hline \multirow[t]{3}{*}{ DQC } & Duque de Caxias & Rio de Janeiro & $22^{\circ} 47^{\prime} \mathrm{S}, 43^{\circ} 18^{\prime} \mathrm{O}$ & Southeast & 2001 & F3 & Females \\
\hline & & & & & 2010 & $\mathrm{~F} 1$ & Males \\
\hline & & & & & 2012 & F0 & Males \\
\hline $\mathrm{FOZ}$ & Foz do Iguaçú & Paraná & $25^{\circ} 32^{\prime} \mathrm{S}, 54^{\circ} 35^{\prime} \mathrm{O}$ & South & 2009 & $\mathrm{~F} 2$ & Females \\
\hline GVD & Governador Valadares & Minas Gerais & $18^{\circ} 50^{\prime} \mathrm{S}, 41^{\circ} 56^{\prime} \mathrm{O}$ & Southeast & 2011 & F1 & Males \\
\hline ITP & Itaperuna & Rio de Janeiro & $21^{\circ} 12^{\prime} \mathrm{S}, 41^{\circ} 53^{\prime} \mathrm{O}$ & Southeast & 2011 & $F 2$ & Males \\
\hline LZN & Luziânia & Goiás & $16^{\circ} 15^{\prime} \mathrm{S}, 47^{\circ} 55^{\prime} \mathrm{O}$ & Central-west & 2011 & F2 & Females \\
\hline MRB & Marabá & Pará & $5^{\circ} 22^{\prime} \mathrm{S}, 49^{\circ} 07^{\prime} \mathrm{O}$ & North & 2011 & F0 & Males \\
\hline \multirow[t]{2}{*}{ MSR } & Mossoró & Rio Grande do Norte & $5^{\circ} 11^{\prime} S, 37^{\circ} 20^{\prime} \mathrm{O}$ & Northeast & 2009 & F0 & Males \\
\hline & & & & & 2011 & F0 & Males \\
\hline$P C R$ & Pacaraima & Roraima & $4^{\circ} 25^{\prime} \mathrm{N}, 61^{\circ} 08^{\prime} \mathrm{O}$ & North & 2011 & F0 & Males \\
\hline PGT & Porangatu & Goiás & $13^{\circ} 25^{\prime} \mathrm{S}, 49^{\circ} 08^{\prime} \mathrm{O}$ & Central-west & 2012 & F0 & Males \\
\hline PNM & Parnamirim & Rio Grande do Norte & $5^{\circ} 54^{\prime} \mathrm{S}, 35^{\circ} 15^{\prime} \mathrm{O}$ & Northeast & 2010 & F0 & Males \\
\hline RVD & Rio Verde & Goiás & $17^{\circ} 47^{\prime} \mathrm{S}, 50^{\circ} 55^{\prime} \mathrm{O}$ & Central-west & 2011 & F0 & Males \\
\hline \multirow[t]{2}{*}{ SGO } & São Gonçalo & Rio de Janeiro & $22^{\circ} 49^{\prime} \mathrm{S}, 43^{\circ} 03^{\prime} \mathrm{O}$ & Southeast & 2002 & F2 & Males \\
\hline & & & & & 2008 & $F 2$ & Males \\
\hline SIP & Santana do Ipanema & Alagoas & $9^{\circ} 21^{\prime} S, 37^{\circ} 14^{\prime} \mathrm{O}$ & Northeast & 2010 & F2 & Maless \\
\hline SMA & São Miguel do Araguaia & Goiás & $13^{\circ} 15^{\prime} \mathrm{S}, 50^{\circ} 09^{\prime} \mathrm{O}$ & Central-west & 2012 & F0 & Males \\
\hline SRO & Santa Rosa & Rio Grande do Sul & $27^{\circ} 52^{\prime} \mathrm{S}, 54^{\circ} 28^{\prime} \mathrm{O}$ & South & 2011 & F1 & Males \\
\hline SSO & São Simão & Goiás & $18^{\circ} 59^{\prime} \mathrm{S}, 50^{\circ} 32^{\prime} \mathrm{O}$ & Central-west & 2011 & $?$ & Males \\
\hline STR & Santarém & Pará & $2^{\circ} 26^{\prime} S, 54^{\circ} 41^{\prime} \mathrm{O}$ & North & 2010 & F0 & Males \\
\hline TCR & Tucuruí & Pará & $3^{\circ} 46^{\prime} \mathrm{S}, 49^{\circ} 40^{\prime} \mathrm{O}$ & North & 2010 & F0 & Males \\
\hline URU & Uruaçu & Goiás & $14^{\circ} 31^{\prime} \mathrm{S}, 49^{\circ} 09^{\prime} \mathrm{O}$ & Central-west & 2011 & F0 & Males \\
\hline \multirow[t]{2}{*}{ VIT } & Vitória & Espírito Santo & $20^{\circ} 18^{\prime} \mathrm{S}, 40^{\circ} 18^{\prime} \mathrm{O}$ & Southeast & 2006 & $\mathrm{~F} 1$ & Males \\
\hline & & & & & 2010 & F0 & Males \\
\hline
\end{tabular}

and PNM were used to amplify the region spanning the $\mathrm{Na}_{V}$ IIIS6 segment with the primers AaEx31P and AaEx31Q (Table 2), as specified elsewhere [14]. The PCR products were purified in S-400 microcolumns (GE Healthcare) according to manufacturer instructions and cloned with CloneJet PCR Cloning Kit (Thermo Scientific). The DNA sequencing was carried out in an ABI377 Sequencer with the Big Dye 3.1 Kit (LifeTechnologies/Applied Biosystems). Sequence analysis was performed using the BioEdit software version 7.2. 
Table 2 Primer sequences

\begin{tabular}{|c|c|c|}
\hline Primer name & Sequence $\left(5^{\prime}-3^{\prime}\right)$ & References \\
\hline $1016 \mathrm{Val}^{+}$(for) & ${ }^{\# \# A C A A A T T G T T T C C C A C C C G C A C C G G ~}$ & {$[12,15]$} \\
\hline $1016 \| \mathrm{e}^{k d r}$ (for) & ${ }^{\# A C A A A T T G T T T C C C A C C C G C A C T G A ~}$ & \\
\hline 1016 comom (rev) & GGATGAACCGAAATTGGACAAAAGC & \\
\hline $1534 \mathrm{Phe}^{+}$(for) & "HCTACTTTGTGTTCTTCATCATATT & [22] \\
\hline 1534 Cys $^{k d r}$ (for) & \#\#TCTACTITGTGTTCTTCATCATGTG & \\
\hline 1534 comom (rev) & TCTGCTCGTTGAAGTTGTCGAT & \\
\hline AaEx31P (for) & TCGCGGGAGGTAAGTTATTG & [14] \\
\hline AaEx31Q (rev) & GTTGATGTGCGATGGAAATG & \\
\hline long 5'-tail & GCGGGCAGGGCGGCGGGGGCGGGGCC & \\
\hline short 5'-tail & GCGGGC & \\
\hline
\end{tabular}

All individuals were genotyped for both 1016 and 1534 sites. Linkage disequilibrium was tested by the online Genepop version 4.2 [23], and since the 1016 and 1534 sites are linked (see Results section), genotypic and allelic frequencies were taken as a single locus. Hardy-Weinberg equilibrium was evaluated by the classical equation [24], being the null hypothesis of equilibrium checked by a chi-square test with three or one degrees of freedom, respectively, when six or three genotypes were evidenced.

\section{Results}

\section{Allele-specific discrimination}

A $20 \mathrm{bp}$ size difference, due to the $5^{\prime}$-GC tail of allele specific primers, enabled the easy discrimination of homozygous and heterozygous genotypes in either a polyacrylamide gel electrophoresis or in dissociation curves through real-time PCR (Figure 1). Electrophoresis revealed products of around 80 and $100 \mathrm{bp}$, respectively for $\mathrm{Ile}^{k d r}$ and $\mathrm{Val}^{+}$(1016 reaction), and 90 and $110 \mathrm{bp}$, respectively for $\mathrm{Phe}^{+}$and $\mathrm{Cys}^{k d r}$ (1534 reaction). The dissociation curve exhibited $\mathrm{Tm}$ of around 76 and $84^{\circ} \mathrm{C}$, respectively for $\mathrm{Il}^{\mathrm{kdr}}$ and Val (1016 reaction), and 77 and $82^{\circ} \mathrm{C}$, respectively for Phe and Cys ${ }^{k d r}$ (1534 reaction). The PCR conditions of annealing temperature, number of cycles and concentration of each primer were crucial to avoid unspecific amplification. All reactions were accompanied by positive controls, each one consisting of the three potential genotypes at the 1016 and 1534 positions, which were obtained by previously genotyped individuals: homozygous wild type, heterozygous, and homozygous $k d r$. As the Phe1534Cys mutation was detected for first time in Brazilian samples, we cloned and sequenced the IIIS6 region (exon 31) of the $A a N a_{V}$ gene of three genotyped populations (CGR, STR and PNM), confirming the primers' specificity. The 350 bp fragments were submitted to GenBank (accession numbers: KF527414 and KF527415, for 1534 Cys ${ }^{k d r}$ and $1534 \mathrm{Phe}^{+}$, respectively). Excluding the site of the 1534 $k d r$ mutation (TTC/TGC), no other polymorphic site was detected relative to the sequence deposited in VectorBase (Liverpool strain).

\section{Genotyping 1016 and $1534 \mathrm{AaNa}_{\mathrm{V}}$ sites in natural populations}

Around 30 Ae. aegypti individuals from each one of 30 distinct Brazilian localities were genotyped for both 1016 and $1534 \mathrm{Na}_{\mathrm{V}}$ sites, totalling 1,112 analyzed mosquitoes. Some localities were sampled two to four times within a ten-year interval. The genotypes of individual mosquitoes for both sites were first calculated independently: 1016 $\mathrm{Val}^{+} / \mathrm{Val}^{+}, \mathrm{Val}^{+} / \mathrm{Ile}^{k d r}$ and $\mathrm{Ile}^{k d r} / \mathrm{Ile}^{k d r}$, and 1534 $\mathrm{Phe}^{+} / \mathrm{Phe}^{+}$, $\mathrm{Phe}^{+} / \mathrm{Cys}^{k d r}$ and $\mathrm{Cys}^{k d r} / \mathrm{Cys}^{k d r}$. These data were used to perform a genotypic linkage disequilibrium analysis and total linkage between them was demonstrated (Fisher's method, $\mathrm{p}<0.001$ ), as expected from two sites placed in the same gene. In this sense both sites were considered as constituents of a single locus, thus evidencing the occurrence of six genotypes in individual mosquitoes (Table 3). Based on the composition of these genotypes, we concluded that three alleles were present in the

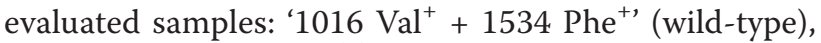
'1016 $\mathrm{Val}^{+}+1534 \mathrm{Cys}^{k d r}$ ' (1534 kdr) and '1016 $\mathrm{Ile}^{k d r}+$ $1534 \mathrm{Cys}^{k d r}$, $(1016 k d r+1534 k d r)$. Hereafter these alleles will be simply referred to as ' $\mathrm{Na}_{\mathrm{V}}{ }^{\mathrm{S}},{ }^{\mathrm{C}} \mathrm{Na}_{\mathrm{V}}{ }^{\mathrm{R} 1}$ ', and ' $\mathrm{Na}_{\mathrm{V}}{ }^{\mathrm{R} 2}$,' respectively (Figure 2). Double mutants and individuals with mutation only in the 1534 position were found (respectively, $\mathrm{Na}_{\mathrm{V}}{ }^{\mathrm{R} 2}$ and ${ }^{\mathrm{N}} \mathrm{Na}_{\mathrm{V}}{ }^{\mathrm{R} 1}$ ); however, in no case was the $1016 k d r$ mutation observed alone, precluding the existence of a $1016 \mathrm{Ile}^{\mathrm{kdr}}+1534 \mathrm{Phe}^{+}$allele in the evaluated populations. Figure 3 shows the frequencies for $\mathrm{Na}_{V}{ }^{\mathrm{S}}, \mathrm{Na}_{\mathrm{V}}{ }^{\mathrm{R} 1}$ and $\mathrm{Na}_{\mathrm{V}}{ }^{\mathrm{R} 2}$ alleles in the most recent samples obtained from each locality. The $95 \%$ CI of the allele frequencies is shown in the Additional file 1: Table S1. According to the alleles, the genotypes were named SS, SR1, SR2, R1R1, R1R2 and R2R2. Their frequencies and the Hardy-Weinberg Equilibrium deviation test are presented in Table 3 . In only seven out of 38 samplings the Hardy-Weinberg Equilibrium assumption was rejected $(\mathrm{p}<0.05)$. No specific genotype contributed to the deviation in these seven localities.

Overall, the distribution of the three alleles differed according to the geographical region (Figure 3). In the North and Northeast Regions, the $\mathrm{Na}_{\mathrm{V}}^{\mathrm{R} 1}$ allele, mutant only at position 1534, was found in all localities, nevertheless the $\mathrm{Na}_{\mathrm{V}}^{\mathrm{S}}$ wild-type allele was the most representative in six of the localities (BEL, CTL, MRB, CAC, SIP and PNM). The highest frequency of $\mathrm{Nav}_{\mathrm{V}}{ }^{\mathrm{R} 1}$, was found in the North: 0.750 (STR), among all populations analyzed. On the other hand, with exception of the most recent AJU (AJU2012), the $\mathrm{Na}_{V}{ }^{\mathrm{R} 2}$ double mutant allele was either absent or $<5 \%$ in the North and Northeast of Brazil. In contrast, the wild-type allele, $\mathrm{Na}_{V}{ }^{\mathrm{S}}$, was absent from 


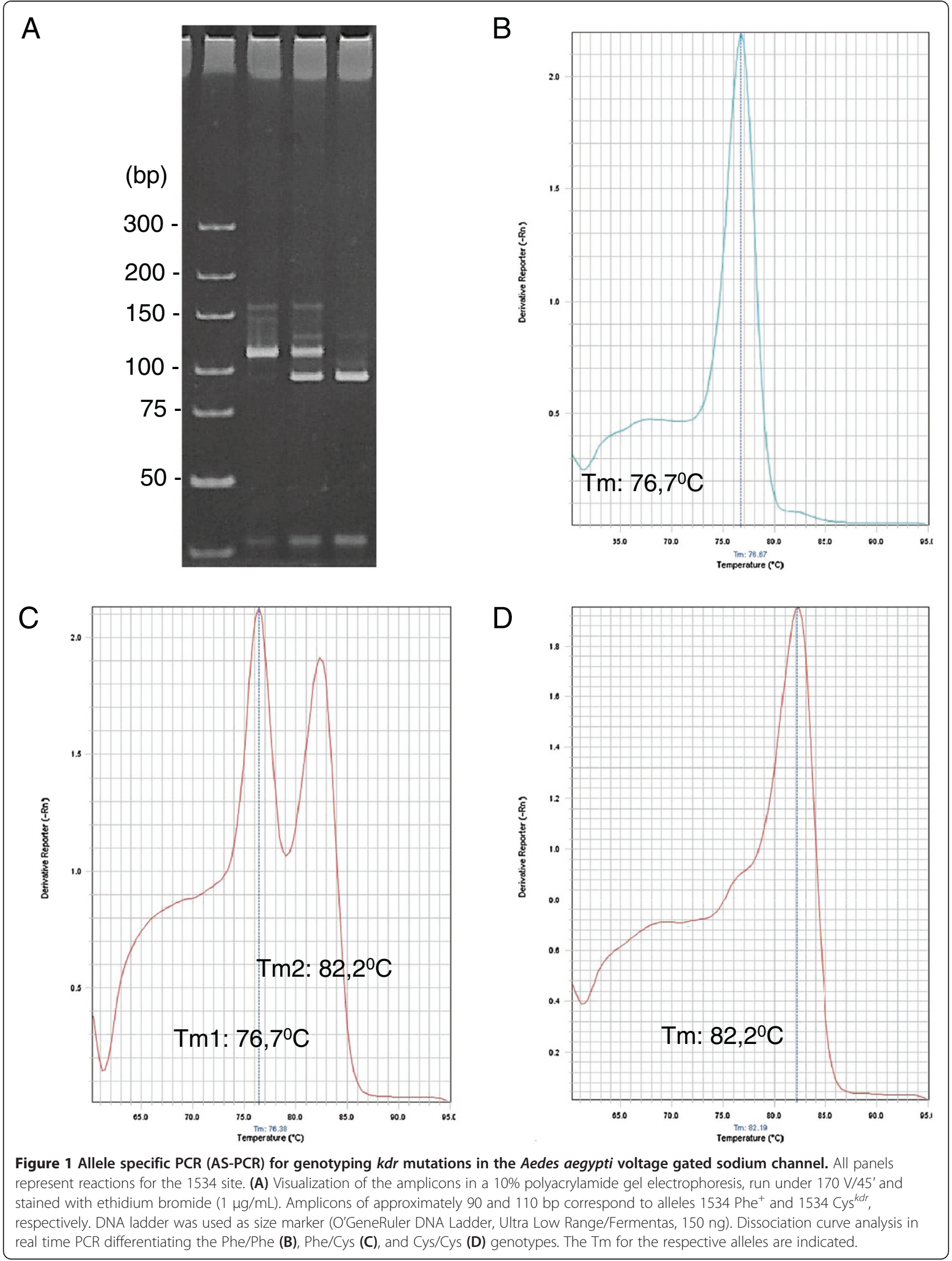


Table 3 Genotype frequencies of Brazilian Aedes aegypti populations at the 1016 and 1534 sites of the $\mathrm{Na}_{\mathrm{V}}$ locus

\begin{tabular}{|c|c|c|c|c|c|c|c|c|c|c|}
\hline \multirow[t]{2}{*}{ Macro-region } & \multirow[t]{2}{*}{ Population } & \multicolumn{6}{|c|}{ Genpotype frequencies } & \multirow[t]{2}{*}{ Total (n) } & \multicolumn{2}{|c|}{ HWE test } \\
\hline & & SS & SR1 & SR2 & R1R1 & R1R2 & $\mathrm{R} 2 \mathrm{R} 2$ & & $x^{2}$ & $p$ \\
\hline \multirow[t]{7}{*}{ North } & PCR11 & 0.000 & 0.000 & 0.000 & 0.367 & 0.467 & 0.167 & 30 & 0.0 & 0.879 \\
\hline & BVT11 & 0.000 & 0.000 & 0.000 & 0.536 & 0.393 & 0.071 & 28 & 0.0 & 0.993 \\
\hline & CAS11 & 0.400 & 0.500 & 0.033 & 0.033 & 0.033 & 0.000 & 30 & 2.3 & 0.512 \\
\hline & BEL10 & 0.536 & 0.357 & 0.000 & 0.107 & 0.000 & 0.000 & 28 & 0.4 & 0.932 \\
\hline & STR10 & 0.200 & 0.100 & 0.000 & 0.700 & 0.000 & 0.000 & 30 & 16.1 & 0.000 \\
\hline & TCR10 & 0.200 & 0.300 & 0.000 & 0.500 & 0.000 & 0.000 & 30 & 3.5 & 0.062 \\
\hline & MRB11 & 0.621 & 0.138 & 0.000 & 0.241 & 0.000 & 0.000 & 29 & 13.3 & 0.000 \\
\hline \multirow[t]{9}{*}{ Northeast } & MSR09 & 0.600 & 0.367 & 0.000 & 0.033 & 0.000 & 0.000 & 30 & 0.2 & 0.660 \\
\hline & MSR11 & 0.000 & 0.767 & 0.000 & 0.200 & 0.000 & 0.033 & 30 & 14.9 & 0.002 \\
\hline & PNM10 & 0.704 & 0.111 & 0.037 & 0.111 & 0.037 & 0.000 & 27 & 9.3 & 0.025 \\
\hline & CAC10 & 0.833 & 0.133 & 0.033 & 0.000 & 0.000 & 0.000 & 30 & 0.0 & 0.998 \\
\hline & SIP10 & 0.433 & 0.500 & 0.067 & 0.000 & 0.000 & 0.000 & 30 & 4.7 & 0.199 \\
\hline & AJU02 & 1.000 & 0.000 & 0.000 & 0.000 & 0.000 & 0.000 & 30 & 0.0 & 1.000 \\
\hline & AJU06 & 0.767 & 0.033 & 0.167 & 0.000 & 0.033 & 0.000 & 30 & 0.3 & 0.955 \\
\hline & AJU10 & 0.269 & 0.038 & 0.308 & 0.000 & 0.000 & 0.385 & 26 & 3.6 & 0.306 \\
\hline & AJU12 & 0.200 & 0.033 & 0.333 & 0.033 & 0.100 & 0.300 & 30 & 3.4 & 0.338 \\
\hline \multirow[t]{9}{*}{ Central-west } & CBL11 & 0.069 & 0.069 & 0.414 & 0.000 & 0.103 & 0.345 & 29 & 0.5 & 0.918 \\
\hline & SMA12 & 0.207 & 0.172 & 0.241 & 0.103 & 0.207 & 0.069 & 29 & 1.2 & 0.750 \\
\hline & PGT12 & 0.000 & 0.069 & 0.241 & 0.241 & 0.241 & 0.207 & 29 & 5.9 & 0.115 \\
\hline & URU11 & 0.233 & 0.133 & 0.300 & 0.000 & 0.100 & 0.233 & 30 & 1.3 & 0.723 \\
\hline & LZN11 & 0.200 & 0.333 & 0.200 & 0.033 & 0.167 & 0.067 & 30 & 1.7 & 0.639 \\
\hline & APG12 & 0.000 & 0.207 & 0.207 & 0.138 & 0.241 & 0.207 & 29 & 2.5 & 0.466 \\
\hline & RVD11 & 0.103 & 0.034 & 0.241 & 0.069 & 0.241 & 0.310 & 29 & 2.8 & 0.421 \\
\hline & SSO11 & 0.000 & 0.133 & 0.033 & 0.200 & 0.233 & 0.400 & 30 & 7.6 & 0.056 \\
\hline & CGR10 & 0.000 & 0.033 & 0.100 & 0.000 & 0.267 & 0.600 & 30 & 1.2 & 0.749 \\
\hline \multirow[t]{11}{*}{ Southeast } & GVD11 & 0.000 & 0.033 & 0.200 & 0.267 & 0.067 & 0.433 & 30 & 18.3 & 0.000 \\
\hline & CLT11 & 0.067 & 0.333 & 0.300 & 0.000 & 0.100 & 0.200 & 30 & 9.0 & 0.029 \\
\hline & VIT06 & 0.267 & 0.100 & 0.333 & 0.000 & 0.033 & 0.267 & 30 & 2.4 & 0.492 \\
\hline & VIT10 & 0.000 & 0.067 & 0.100 & 0.000 & 0.000 & 0.833 & 30 & 2.3 & 0.507 \\
\hline & CIT12 & 0.000 & 0.069 & 0.138 & 0.103 & 0.172 & 0.517 & 29 & 3.8 & 0.281 \\
\hline & ITP11 & 0.148 & 0.111 & 0.259 & 0.074 & 0.074 & 0.333 & 27 & 5.0 & 0.172 \\
\hline & SGO02 & 1.000 & 0.000 & 0.000 & 0.000 & 0.000 & 0.000 & 30 & 0.0 & 1.000 \\
\hline & SGO08 & 0.192 & 0.231 & 0.308 & 0.115 & 0.115 & 0.038 & 26 & 1.6 & 0.669 \\
\hline & DQC01 & 1.000 & 0.000 & 0.000 & 0.000 & 0.000 & 0.000 & 30 & 0.0 & 1.000 \\
\hline & DQC10 & 0.000 & 0.033 & 0.067 & 0.100 & 0.067 & 0.733 & 30 & 13.0 & 0.005 \\
\hline & DQC12 & 0.000 & 0.033 & 0.000 & 0.000 & 0.433 & 0.533 & 30 & 5.6 & 0.136 \\
\hline \multirow[t]{2}{*}{ South } & FOZO9 & 0.133 & 0.100 & 0.400 & 0.033 & 0.000 & 0.333 & 30 & 3.6 & 0.311 \\
\hline & SRO11 & 0.296 & 0.259 & 0.222 & 0.037 & 0.000 & 0.185 & 27 & 7.4 & 0.059 \\
\hline
\end{tabular}

the two northernmost localities evaluated (PCR and BVT, both in the State of Roraima), where both mutant alleles were at high frequencies. In all localities from Central-West, Southeast and South regions, all three alleles were present. The most frequent allele was the
$\mathrm{NaV}^{\mathrm{R} 2}$ double mutant. Exceptions were LZN, SMA, URU, $\mathrm{SGO}$ and SRO, where the $\mathrm{Na}_{\mathrm{V}}{ }^{\mathrm{S}}$ wild-type allele was the most representative (Figure 3 ).

The dynamics of the genotype frequencies was analyzed in AJU, MSR, VIT and DQC. Samples from AJU were 


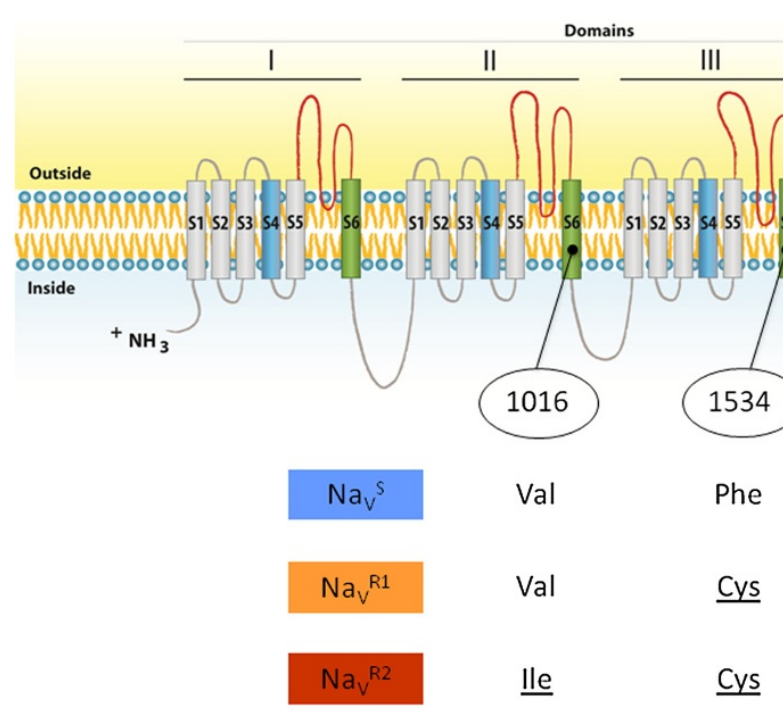

Figure 2 Voltage gated sodium channel and the 1016 and 1534 alleles found in Brazilian Aedes aegypti populations. The Nay is represented with its four domains (I-IV), each with the six transmembrane segments (S1-S6). The voltage sensitive S4 and the pore forming S6 segments are colored in blue and green, respectively (scheme adapted from [9]). The 1016 and 1534 kdr sites in Aedes aegypti are indicated. Mutant amino acids are underlined.

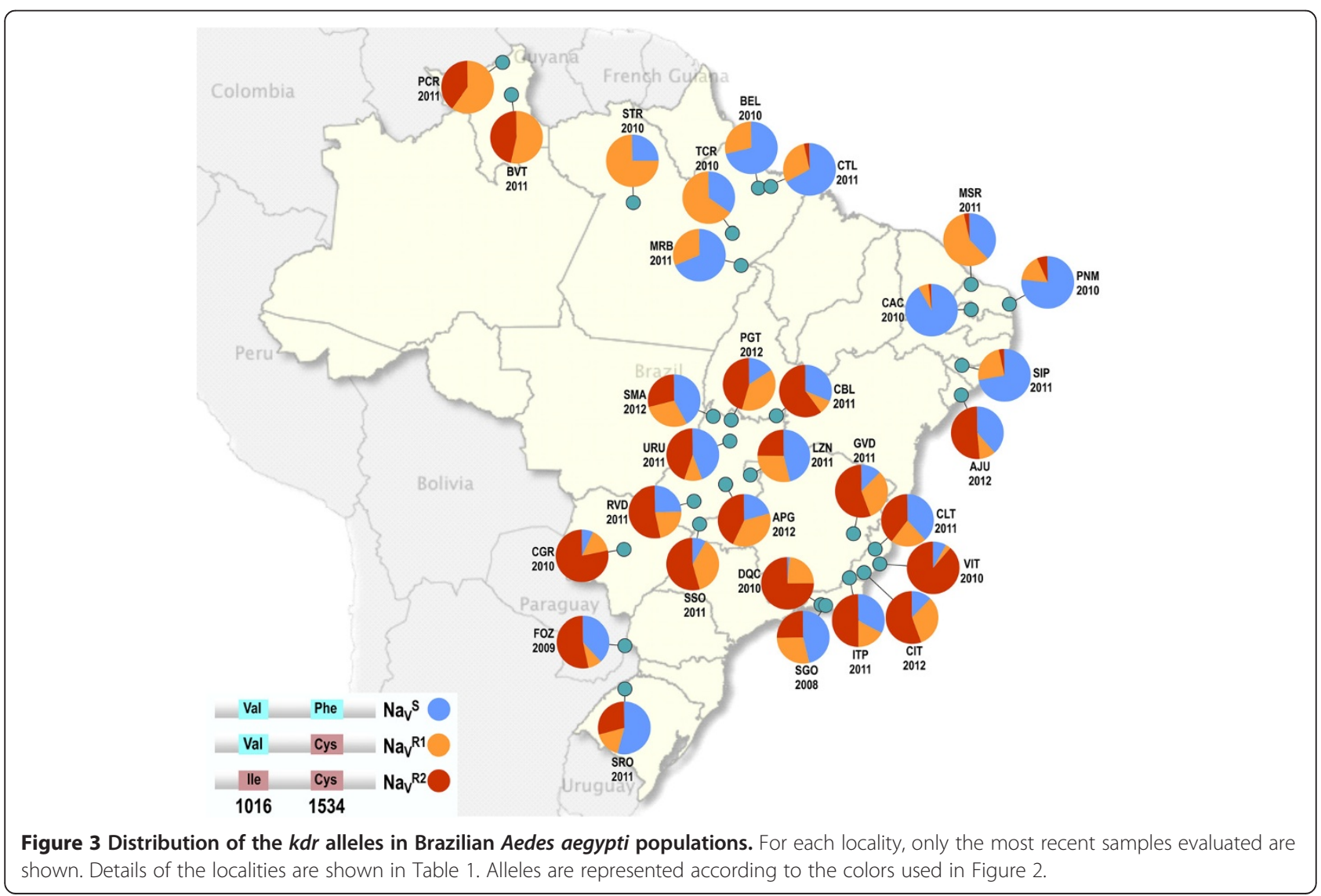


collected four times in the course of a decade, between 2002 and 2012. In 2002, only the $\mathrm{Na}_{V}{ }^{\mathrm{S}}$ wild-type allele was detected. The $k d r$ alleles appeared first in 2006 and the double mutant $\mathrm{NaV}_{\mathrm{V}}^{\mathrm{R} 2}$ was the most frequent allele by 2012 (Figure 4). Accordingly, the 'SS' wild-genotype progressively decayed from $100 \%$ in 2002 to $20 \%$ in 2012 , when the double mutant 'R2R2' represented $30 \%$ of the individuals, and was the most frequent genotype (AJU2012, Table 3). The frequency of the $\mathrm{Na}_{V}{ }^{S}$ wild-type allele also decreased in all other localities evaluated where the $k d r$ alleles increased in frequency (Figure 4). Except for MSR, the $\mathrm{Na}_{\mathrm{V}}{ }^{\mathrm{R} 2}$ double mutant is likely to be the most favorably selected allele. It is noteworthy that in AJU, the $\mathrm{Na}_{\mathrm{V}}{ }^{\mathrm{R} 1}$ allele showed the larger frequency increase, probably because $\mathrm{Na}_{\mathrm{V}}^{\mathrm{R} 2}$ must have arrived to the Northeast more recently.

\section{Discussion}

The genotyping of mutations directly related to insecticide resistance is an important surveillance tool for agricultural and sanitary purposes. Among selected mechanisms of pyrethroid resistance, $k d r$ mutations in the voltage gated sodium channel $\left(\mathrm{Na}_{\mathrm{V}}\right)$ are those that better correlate particular genotypes with insecticide resistance [25]. The increased efficiency of insecticide detoxification, known as metabolic resistance - involving super families of enzymes such as GST, esterases and especially the multi function oxidases P450 - may also confer resistance to pyrethroids. However, identification of these mechanisms is mainly based on enzymatic assays of low specificity [26] or on bioassays with synergist compounds [27], and are not clearly linked to particular genes. More recently, many successful transcriptome tools for metabolic resistance genes have emerged, pointing to a very complex and diverse scenario regarding insecticide selected genes and their pattern of expression among insect populations $[28,29]$. Because the metabolic resistance based selection seems to have a high fitness cost, due to reallocation of energetic resources, this mechanism is expected to induce lower resistance levels, if compared to mutations in the target site molecules [30]. This was corroborated by laboratory selection with pyrethroids in an Ae. aegypti lineage: increase of the $1016 \mathrm{Ile}^{k d r}$ frequency was inversely proportional to the number of 'metabolic' genes differentially transcribed [29]. It was hypothesized that, in the presence of pyrethroid, $k d r$ mutations are preferentially selected among other mechanisms, contributing to higher resistance levels and/or resulting in less deleterious effects.

In addition to the classical Leu1014Phe $k d r$ mutation, several others have been associated with pyrethroid resistance [6]. Interactions of multiple $\mathrm{Na}_{V}$ mutations may modulate pyrethroid resistance levels. For instance, certain $\mathrm{Na}_{V}$ haplotypes, including synonymous substitutions, were found in two distinct field populations of Culex quinquefasciatus selected for pyrethroid resistance during 6-8 generations in the laboratory. It was suggested that some of these haplotypes were selected at an early stage of permethrin resistance and later evolved to other mutation combinations in the course of selection pressure [31]. In Ae. aegypti, a synonymous substitution at exon 20,

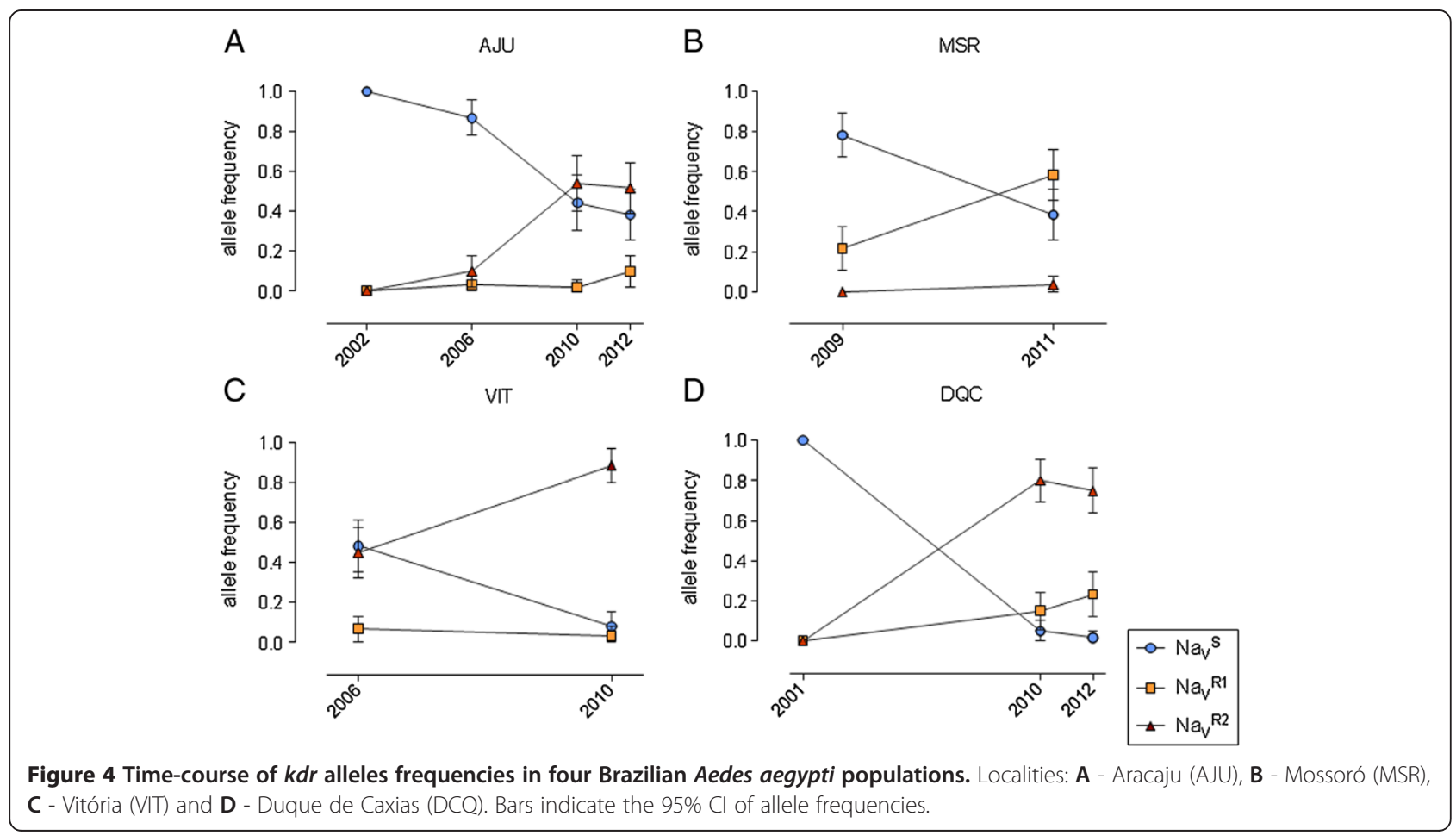


together with an extensive polymorphism in the following intron, were linked to both Ile1011Met and Val1016Ile mutations [15,32]. Additionally, a gene duplication event was recently described in the $A a N a_{V}$ of natural populations and in a laboratory strain selected for pyrethroid resistance [33]. Although there are at least seven different mutations described in the $A a N a_{V}$, only those corresponding to the 1016 and 1534 positions are clearly related to resistance; both are placed in a domain of the sodium channel that interacts directly with the pyrethroid molecule [34].

There are two mutations described in the $A a \mathrm{Na}_{\mathrm{V}} 1016$ site, Val to Ile or Gly, respectively in Latin America $[12,14,15]$ and in Southeast Asia [35]. In Brazil, we found no evidence of a haplotype that contains exclusively the $1016 \mathrm{Ile}^{k d r}$ mutation, since it was always found together with 1534 $\mathrm{Cys}^{k d r}\left(\mathrm{Na}_{\mathrm{V}}{ }^{\mathrm{R} 2}\right.$ allele, herein). Nevertheless, we are aware that it is possible for a haplotype carrying the $1016 k d r$ mutation to occur in the populations examined, however, it would be present at very low frequencies. Actually, this putative allele must have occurred in two out of three Ae. aegypti populations from Grand Cayman, given that the $1016 \mathrm{Ile}^{k d r}$ presented a higher frequency than the 1534 $\mathrm{Cys}^{k d r}$ substitution [14].

Differently from the 1016 position, only one substitution, Phe/Cys, was found in the 1534 site by far $[14,36]$. This 1534 substitution can be linked with another one. In Thailand, the $1534 \mathrm{Cys}^{k d r}$ co-occurred with $1016 \mathrm{Gly}^{k d r}$ and $989 \mathrm{Pro}^{k d r}$ in the same molecule [22]. In that region an allele $1534 \mathrm{Cys}^{k d r}$ without mutation in 1016 site $\left(\mathrm{Na}_{\mathrm{V}}{ }^{\mathrm{R} 1}\right.$ allele, herein) seemed to be very common, since its frequency was higher than the 1016 Gly $^{k d r}$ [35].

Here we presented the distribution of the $k d r$ variants for the $\mathrm{AaNa}_{\mathrm{V}}$, considering both 1016 and 1534 sites screen from several natural Brazilian populations. We considered that once these sites are very close in the genome, reporting the allele/genotypic frequencies of each site separately would not be fully informative. However, because there are still some gaps concerning the actual role of these mutations in pyrethroid resistance, regarding whether they are acting alone or synergistically, and present in cis or trans mutations, we are reporting the allele frequencies of each site rather than as an haplotype. The implication of the $1016 \mathrm{Ile}^{k d r}$ allele in resistance to pyrethroids was corroborated by laboratory selection, which highly increased the allelic frequency up to fixation in only five generations [29]. Accordingly, in the last decade this mutation has been rapidly spreading in natural populations from Brazil and Mexico, concomitantly with the intensification of pyrethroid usage due to the emergence of severe dengue outbreaks $[15,16]$. In these cases however, the co-occurrence of the $1534 \mathrm{Cys}^{k d r}$ mutation has been overlooked. A recent study reported high frequencies of $1534 \mathrm{Cys}^{k d r}$ in Grand Cayman [14], suggesting it is not a novel mutation in Latin America. In a recent report, nine single and two double $A a N a_{V}$ mutants were constructed and inserted in a Xenopus oocyte system in order to perform functional evaluations of these substitutions in the presence of type I or II pyrethroids [34]. The 1016 $\mathrm{Ile}^{k d r}$ construct did not result in sensitivity reduction, to either pyrethroid types. On the other hand, the 1534 $\mathrm{Cys}^{k d r}$ significantly diminished the $\mathrm{AaNa}_{\mathrm{V}}$ sensibility to type I but not to type II pyrethroids. This same substitution in the homologous $k d r$ site of the cockroach $\mathrm{Na}_{\mathrm{V}}$ exhibited similar results [37].

An Ae. aegypti lineage, selected for permethrin resistance in the laboratory, exhibited high frequencies of 1016 $\mathrm{Gly}^{k d r}+1794 \mathrm{Tyr}^{\mathrm{kdr}}$ substitutions in the same molecule, which suggested a synergistic effect towards pyrethroid resistance [38]. We hypothesize that mutation in the 1016 site should be important when in synergism with other specific mutations. In Brazil, the $1534 \mathrm{Cys}^{k d r} \mathrm{mu}-$ tation is widespread throughout the territory. The $\mathrm{Na}_{V}^{\mathrm{R} 1}$ allele is more frequent in North/Northeast regions whereas $\mathrm{Na}_{V}{ }^{\mathrm{R} 2}$ is more commonly present in Central/ Southeast regions, generally where the highest resistance levels to pyrethroids are observed [18]. Both mutant haplotypes appear to be rapid and favorably selected in all evaluated populations. However, in the most recent samplings the $\mathrm{Na}_{V}{ }^{\mathrm{R} 2}$ double mutant was the more frequent $k d r$ allele. The exception was MSR, in the Northeast Region, where $\mathrm{Na}_{\mathrm{V}}{ }^{\mathrm{R} 2}$ was only recently introduced. Together these data suggest that $\mathrm{Na}_{\mathrm{V}}{ }^{\mathrm{R} 2}$ allele would be more advantageous for pyrethroid resistance, or impose a lower fitness cost when compared to $\mathrm{Na}_{\mathrm{V}}{ }^{\mathrm{R} 1}$. We recently demonstrated that an $\mathrm{Na}_{\mathrm{V}}{ }^{\mathrm{R} 2}$ homozygous $A e$. aegypti lineage, highly resistant to pyrethroids, exhibited a fitness cost in a series of life-trait parameters [39]. Further comparisons between $\mathrm{Na}_{\mathrm{V}}{ }^{\mathrm{R}}$ and $\mathrm{Na}_{V}{ }^{\mathrm{R} 2}$ lineages will be of importance to better clarify those assumptions.

It is of note that since 2001 and up to 2009 the Brazilian Dengue Control Program employed pyrethroids in ultralow volume applications in several municipalities as part of the effort to control the dengue vector [18]. With very few exceptions, the basis for pyrethroid selection pressure derived from national campaigns is essentially the same in the whole country. Therefore, differential selection pressures would not explain the aforementioned regionalization of the $k d r$ alleles. It is likely that the current distribution of the $k d r$ alleles reflects distinct Ae. aegypti populations that colonized the continent. Population genetics analysis of neutral loci will help us to unravel the evolutionary routes of these resistance genes.

\section{Conclusions}

In conclusion, pyrethroids are the most employed insecticides worldwide and the only chemical class presently allowed in long lasting treated materials, such as nets 
and curtains [40]. Although novel control strategies are being tested in the field, such as those based on transgenic and on Wolbachia-infected mosquitoes [2,41,42], insecticides will certainly play an important role for yet a long time. Knowledge of the sodium channel diversity in natural populations together with the role of each allele regarding pyrethroid resistance as well as their fitness effects are crucial for preserving the effectiveness of this class of compounds as a viable tool against Ae. aegypti.

\section{Additional file}

Additional file 1: Table S1. Kdr allele frequencies of Aedes aegypti natural populations from Brazil. The Cl95\%* is under parentheses.

\section{Competing interests}

The authors declare that they have no competing interests.

\section{Authors' contributions}

Conceived and designed the experiments: JGBL, LPB, AJM. Performed the experiments: JGBL, LPB, GAG. Analyzed the data: JGBL, LPB, ASA, RVB, AJM Contributed reagents/materials/analysis tools: RVB, JBPL, DV. Wrote the paper: AJM, DV. All authors read and approved the final version of the manuscript.

\section{Acknowledgements}

We thank Dr Alexandre Afranio Peixoto for his friendship and orientation throughout this study. This work is dedicated to his memory. We also thank the DNA sequencing facility of FIOCRUZ (Plataforma de Sequenciamento/ PDTIS/Fiocruz) and the Brazilian Dengue Control Program that allowed utilization of samples collected in the scope of the Brazilian Aedes aegypti Insecticide Resistance Monitoring Network (MoReNAa). We are grateful to Dr Andrea Gloria-Soria for critical reading the manuscript.

\section{Author details}

'Laboratório de Fisiologia e Controle de Artrópodes Vetores, Instituto Oswaldo Cruz - FIOCRUZ, Rio de Janeiro, RJ, Brazil. '²aboratório de Entomologia, Instituto de Biologia do Exército, Rio de Janeiro, RJ, Brazil. "'Laboratório de Biologia Molecular de Insetos, Instituto Oswaldo Cruz - FIOCRUZ, Rio de Janeiro, RJ, Brazil. ${ }^{4}$ Instituto Nacional de Ciência e Tecnologia em Entomologia Molecular, Rio de Janeiro, RJ, Brazil. ${ }^{5}$ Laboratório de Biologia Molecular de Flavivirus, Instituto Oswaldo Cruz - FIOCRUZ, Rio de Janeiro, R, Brazil.

Received: 12 August 2013 Accepted: 18 December 2013 Published: 15 January 2014

\section{References}

1. Guzman MG, Halstead SB, Artsob H, Buchy P, Farrar J, et al: (2010) Dengue: a continuing global threat. Nat Rev Microbiol 2010, 8:S7-S16.

2. Maciel-de-Freitas R, Aguiar R, Bruno RV, Guimaraes MC, Lourenco-de-Oliveira $R$, et al: Why do we need alternative tools to control mosquito-borne diseases in Latin America? Mem Inst Oswaldo Cruz 2012, 107:828-829.

3. WHOPES: Pesticides and their application for the control of vectors and pests of public health importance (WHO/CDS/NTD/WHOPES/GCDPP/2006.1). Geneva: World Health Organization; 2006.

4. Agency USEP: Pesticides: Regulating Pesticides. U.S. Environmental Protection Agency; 2012. http://www.epa.gov/oppsrrd1/reevaluation/pyrethroidspyrethrins.html.

5. Ranson H, Burhani J, Lumjuan N, Black WC IV: Insecticide resistance in dengue vectors. Trop/KAnet 2010, 1:1. cited 2013-12-02], pp. 0-0. Available from: http://journal.tropika.net/scielo.php?script=sci_arttext\&pid=S207886062010000100003\&lng=en\&nrm=iso. ISSN 2078-8606.

6. Dong K: Insect sodium channels and insecticide resistance. Invert Neurosci 2007, 7:17-30

7. Catterall WA: From ionic currents to molecular mechanisms: the structure and function of voltage-gated sodium channels. Neuron 2000, 26:13-25.
8. ffrench-Constant RH, Pittendrigh B, Vaughan A, Anthony N: Why are there so few resistance-associated mutations in insecticide target genes? Philos Trans R Soc Lond B Biol Sci 1998, 353:1685-1693.

9. Martins AJ, Valle D: The pyrethroid knockdown resistance. In Insecticides - Basic and Other Applications. Edited by Soloneski S, Larramendy M. Rijeka: InTech; 2012:17-38.

10. O'Reilly AO, Khambay BP, Williamson MS, Field LM, Wallace BA, et al: Modelling insecticide-binding sites in the voltage-gated sodium channel. Biochem J 2006, 396:255-263.

11. Davies TG, Field LM, Usherwood PN, Williamson MS: A comparative study of voltage-gated sodium channels in the Insecta: implications for pyrethroid resistance in Anopheline and other Neopteran species. Insect Mol Biol 2007, 16:361-375.

12. Saavedra-Rodriguez $K$, Urdaneta-Marquez $L$, Rajatileka S, Moulton M, Flores AE, et al: A mutation in the voltage-gated sodium channel gene associated with pyrethroid resistance in Latin American Aedes aegypti. Insect Mol Biol 2007, 16:785-798.

13. Brengues C, Hawkes NJ, Chandre F, McCarroll L, Duchon S, et al: Pyrethroid and DDT cross-resistance in Aedes aegypti is correlated with novel mutations in the voltage-gated sodium channel gene. Med Vet Entomol 2003, 17:87-94.

14. Harris AF, Rajatileka S, Ranson H: Pyrethroid resistance in Aedes aegypti from Grand Cayman. Am J Trop Med Hyg 2010, 83:277-284.

15. Martins AJ, Lima JB, Peixoto AA, Valle D: Frequency of Val1016lle mutation in the voltage-gated sodium channel gene of Aedes aegypti Brazilian populations. Trop Med Int Health 2009, 14:1351-1355.

16. Garcia GP, Flores AE, Fernandez-Salas I, Saavedra-Rodriguez K, Reyes-Solis G, et al: Recent rapid rise of a permethrin knock down resistance allele in Aedes aegypti in Mexico. PLoS Negl Trop Dis 2009, 3:e531.

17. Marcombe S, Mathieu RB, Pocquet N, Riaz MA, Poupardin R, et al: Insecticide resistance in the dengue vector Aedes aegypti from Martinique: distribution, mechanisms and relations with environmental factors. PLoS One 2012, 7:e30989.

18. Montella IR, Martins AJ, Viana-Medeiros PF, Lima JB, Braga IA, et al: Insecticide resistance mechanisms of Brazilian Aedes aegypti populations from 2001 to 2004. Am J Trop Med Hyg 2007, 77:467-477.

19. Okimoto R, Dodgson JB: Improved PCR amplification of multiple specific alleles (PAMSA) using internally mismatched primers. Biotechniques 1996 , 21:20-22. 24, 26.

20. Germer S, Higuchi R: Single-tube genotyping without oligonucleotide probes. Genome Res 1996, 9:72-78.

21. Wang J, Chuang K, Ahluwalia M, Patel S, Umblas N, et al: High-throughput SNP genotyping by single-tube PCR with Tm-shift primers. Biotechniques 2005, 39:885-893

22. Yanola J, Somboon P, Walton C, Nachaiwieng W, Somwang P, et al: High-throughput assays for detection of the F1534C mutation in the voltage-gated sodium channel gene in permethrin-resistant Aedes aegypti and the distribution of this mutation throughout Thailand. Trop Med Int Health 2011, 16:501-509.

23. Raymond M, Rousset F: Genepop (Version-1.2) - population-genetics software for exact tests and ecumenicism. J Hered 1995, 86:248-249.

24. Shorrocks B: The Genesis of Diversity. London: Hodder and Stoughton; 1978.

25. Donnelly MJ, Corbel V, Weetman D, Wilding CS, Williamson MS, et al: Does kdr genotype predict insecticide-resistance phenotype in mosquitoes? Trends Parasitol 2009, 25:213-219.

26. Valle D, Montella IR, Medeiros PFV, Ribeiro RA, Martins AJ, et al: Quantification methodology for enzyme activity related to insecticide resistance in Aedes aegypti. Ministério da Saúde/Brasil: Brasília; 2006.

27. Brogdon WG, McAllister JC: Simplification of adult mosquito bioassays through use of time-mortality determinations in glass bottles. J Am Mosq Control Assoc 1998, 14:159-164

28. Bariami V, Jones CM, Poupardin R, Vontas J, Ranson H: Gene amplification, $A B C$ transporters and cytochrome P450s: unraveling the molecular basis of pyrethroid resistance in the dengue vector, Aedes aegypti. PLoS Negl Trop Dis 2012, 6:e1692.

29. Saavedra-Rodriguez K, Suarez AF, Salas IF, Strode C, Ranson H, et al: Transcription of detoxification genes after permethrin selection in the mosquito Aedes aegypti. Insect Mol Biol 2012, 21:61-77.

30. Martins AJ, Ribeiro CD, Bellinato DF, Peixoto AA, Valle D, et al: Effect of insecticide resistance on development, longevity and reproduction of field or laboratory selected Aedes aegypti populations. PLoS One 2012, 7:e31889. 
31. Xu Q, Zhang L, Li T, Zhang L, He L, et al: Evolutionary adaptation of the amino acid and codon usage of the mosquito sodium channel following insecticide selection in the field mosquitoes. PLoS One 2012, 7:e47609.

32. Martins AJ, Lins RM, Linss JG, Peixoto AA, Valle D: Voltage-gated sodium channel polymorphism and metabolic resistance in pyrethroid-resistant Aedes aegypti from Brazil. Am J Trop Med Hyg 2009, 81:108-115.

33. Martins AJ, Brito LP, Linss JGB, Rivas GB, Machado R, et al: Evidence for gene duplication in the voltage gated sodium channel gene of Aedes aegypti. EMPH 2013:eoto12v1-eot012.

34. Du Y, Nomura Y, Satar G, Hu Z, Nauen R, et al: Molecular evidence for dual pyrethroid-receptor sites on a mosquito sodium channel. Proc Natl Acad Sci USA 2013:1305118110v1-1305118110v201305118.

35. Kawada H, Higa Y, Komagata O, Kasai S, Tomita T, et al: Widespread distribution of a newly found point mutation in voltage-gated sodium channel in pyrethroid-resistant Aedes aegypti populations in Vietnam. PLoS Negl Trop Dis 2009, 3:e527.

36. Yanola J, Somboon P, Walton C, Nachaiwieng W, Prapanthadara LA: A novel F1552/C1552 point mutation in the Aedes aegypti voltage-gated sodium channel gene associated with permethrin resistance. Pestic Biochem Physiol 2010, 96:127-131.

37. $\mathrm{Hu} Z$, Du $Y$, Nomura $Y$, Dong $K$ : A sodium channel mutation identified in Aedes aegypti selectively reduces cockroach sodium channel sensitivity to type I, but not type II pyrethroids. Insect Biochem Mol Biol 2011, 41:9-13.

38. Chang C, Shen WK, Wang TT, Lin YH, Hsu EL, et al: A novel amino acid substitution in a voltage-gated sodium channel is associated with knockdown resistance to permethrin in Aedes aegypti. Insect Biochem Mol Biol 2009, 39:272-278.

39. Brito LP, Linss JG, Lima-Camara TN, Belinato TA, Peixoto AA, et al: Assessing the effects of Aedes aegypti kdr mutations on pyrethroid resistance and its fitness cost. PLoS One 2013, 8:e60878.

40. Zaim M, Aitio A, Nakashima N: Safety of pyrethroid-treated mosquito nets. Med Vet Entomol 2000, 14:1-5.

41. Walker T, Johnson PH, Moreira LA, Iturbe-Ormaetxe I, Frentiu FD, et al: The wMel Wolbachia strain blocks dengue and invades caged Aedes aegypti populations. Nature 2011, 476:450-453.

42. Harris AF, Nimmo D, McKemey AR, Kelly N, Scaife S, et al: Field performance of engineered male mosquitoes. Nat Biotechnol 2011, 29:1034-1037.

doi:10.1186/1756-3305-7-25

Cite this article as: Linss et al:: Distribution and dissemination of the Val1016lle and Phe1534Cys Kdr mutations in Aedes aegypti Brazilian natural populations. Parasites \& Vectors 2014 7:25.

\section{Submit your next manuscript to BioMed Central and take full advantage of:}

- Convenient online submission

- Thorough peer review

- No space constraints or color figure charges

- Immediate publication on acceptance

- Inclusion in PubMed, CAS, Scopus and Google Scholar

- Research which is freely available for redistribution

Submit your manuscript at www.biomedcentral.com/submit 